Brit. J. vener. Dis. (1960), 36, 10.

\title{
RECENT ACHIEVEMENTS OF A NON-GOVERNMENTAL ORGANIZATION IN V.D. CONTROL*
}

\author{
BY \\ E. GURNEY CLARK $†$ AND CONRAD VAN HYNING $\ddagger$
}

American Social Hygiene Association

The American Social Hygiene Association, the United States member agency of the Union, was organized (in 1914) by a group of leaders who were aware of the need and value of a non-governmental organization in all its implications. The Association's programme has always had as its goal the preservation of the family unit and, as such, has studied the problems of family deterioration, particularly venereal disease and prostitution. This recognized need included, even then, the awareness of the importance of international as well as national perspective.

The Association's long history and achievements have been consistent with its awareness of the potential of the non-governmental organization: namely, that it has the unique quality of independence, of representing and acting upon public opinion, the power of initiative, and true flexibility in its action.

The Association's experience has shown further that the role of the non-governmental organization is one of support and co-operation to government programmes in the same field and, as such, it is not competitive with government. Its disassociation from politics makes it a welcome partner to official programmes. As intra-governmental action expands, the non-governmental organization acts as a balance by initiating new programmes and watching over continuing programmes where the understandably slow wheels of government cannot always adjust quickly to changing needs. The non-governmental organization, with its many and varied contacts, is also

\footnotetext{
* Presented to the General Assembly of the I.U.V.D.T., London, October 13, 1959.

$t$ Professor of Epidemiology, School of Public Health and Administrative Medicine, Columbia University; Medical Consultant, American Social Hygiene Association.

$\ddagger$ Executive Director, American Social Hygiene Association.
}

an important source of leadership for government projects.

The functions of a non-governmental organization were well described recently by a committee of the American Public Health Association which is considering a plan for a training programme for the executives of non-governmental agencies operating on local, state, and national levels in the United States:

"A voluntary health association is made up of publicspirited citizens who have organized formally for the purpose of improving the health of the public. One such association may concentrate on a specific health problem as related to more general health needs, whereas another may be concerned with the health situation as a whole. It usually operates independently of governmental health agencies, though in close cooperation with them ... The functions of voluntary health associations vary in detail at the national, state, and local levels, depending in part upon the organizational pattern of the national organization and its local affiliates ... A voluntary health agency seeks to gain new knowledge, not only in its particular fields of interest, but also in the way a community functions. It tries to see that knowledge is applied to improve the health of individuals and to help solve community health problems, implemented largely through programmes in which members of the community participate . . A voluntary health agency endeavours to identify and survey special health problems and to support research on these problems."

The characteristics and functions of non-governmental organizations as described above are reflected in the recent achievements of the American Social Hygiene Association (A.S.H.A.) in V.D. control in the United States. Consistent with these principles, the A.S.H.A. has collaborated with professional 
health organizations and government health agencies in order to gain new knowledge through epidemiological surveys and social research, and to use this knowledge for public information, both nationally and internationally, to influence health improvement.

\section{EPIDEMIOLOGICAL SURVEYS}

For the past 6 years the A.S.H.A., in collaboration with the American Venereal Disease Association and the Association of State and Territorial Health Officers, has made annual surveys of the status of V.D. and its control in the U.S.A. by means of questionnaires sent to all States, to cities of 100,000 or more population, and to all territories. The planning committee for these surveys represents the three sponsoring organizations and the U.S. Public Health Service, the Army, the Navy, and the Air Corps. Because so many of the reported evaluations of V.D. statistics were based on data relating to the problems of nations as a whole rather than to the problems in specific local areas, the primary objective of these surveys was to secure specific information from local areas to direct attention to the actual nature, extent and significance of V.D. problems in all parts of the U.S.A. This was needed to discourage the notion suggested by national rates that syphilis and gonorrhoea are "dying diseases", and to encourage increased vigilance among city and county health departments.

These surveys have provided evidence that V.D. increased in many states and cities each year, although there was a constant decrease in syphilis nationally from 1943 and in gonorrhoea nationally from 1947 until 1956. They also revealed that rates for states and cities tend to conceal high prevalence in certain areas within them. For example, in 1958, this was said to be true in 34 states and 47 cities.

Each year detailed statements of the annual V.D. problem have been distributed throughout the U.S.A. The achievements of the surveys are as follows:

(1) The reawakening of concern for V.D. problems among many professional workers as proved by personal contact and by correspondence.

(2) Changes in the opinions of political leaders, resulting in annual increases in federal and local appropriations for V.D. control. (Each year the ASHA has been invited to present facts on V.D. problems before congressional appropriations committees.)

(3) Stimulation of social research to learn more about factors leading to V.D. infections. The background for this research effort is stated in the joint statement ("Today's V.D. Control Problem" for the fiscal year 1958) published in February, 1959. This joint statement is, therefore, more than an inventory of infection, rate of infection, and facilities to find and treat. It is a report on one of the factors in a syndrome of social illness which has serious implications for all of us and which deserves careful study.

\section{SOCIAL RESEARCH}

In 1956 the A.S.H.A. organized a "Steering and Planning Committee for Teenage V.D. Studies". At the first meeting of this Committee, in October, 1956, the following objectives were proposed:

(1) To collect information on how teenagers get their sex education and of what it consists.

(2) To determine the relationship between the incidence of teenage V.D. and family instability.

(3) To discover the family and community conditions which predispose to teenage promiscuity.

(4) To develop better public health methods for eliminating V.D. as a health hazard.

(5) To develop a body of information not now in existence which can direct our efforts toward strengthening and protecting the family against the varied forces which in our time tend to divide it.

In 1957-58, three research projects on teenage sex behaviour were set up by this Committee. Financed by grants from several sources, these three pilot projects are now being carried on by social workers, sociologists, and anthropologists at the University of California, Los Angeles, at Washington University, St. Louis, and in the Boston-Cambridge area under the guidance of Harvard University staff.

The achievement of the A.S.H.A. in promoting these three research projects has led to another request for A.S.H.A. collaboration in planning and conducting a study of approximately 500 teenage V.D. patients in the care of clinics of the New York City Department of Health. Funds for the project were provided by the U.S. Public Health Service. The primary reason for this project was that the U.S. Public Health Service wanted guide lines for improving interviewing techniques and also to elicit information concerning general social and sexual behaviour and the factors underlying it. An outstanding expert in social research was employed to direct this joint project of the U.S. Public Health Service, the New York City Department of Health, and A.S.H.A., and it is now in operation.

\section{FAmily Life Education}

The Association has long held that the dynamics of behaviour and the understanding of one's personal and social environment are fundamental to the prevention and control of the venereal diseases. A.S.H.A has therefore placed more emphasis in recent years 
on a programme of family life education which encompasses Foundation-supported projects in almost half the states of this country, and which has produced curricular guides and other informational brochures used throughout the United States and in a number of foreign lands. These projects represent an essential preventive approach to the problems posed by V.D. and other forms of personal and social disorder.

\section{Prostitution}

Recognizing prostitution as a symptom of family breakdown, the Association has tried to reduce commercialized prostitution by the education of groups of citizens within the United States concerned with this problem and by making periodic surveys of prostitution conditions. An example of a recent achievement in this field has been the material and historical data given by the Association to the U.S. Delegation to the 12th Session of the Social Commission of the United Nations in its consideration of the U.N. Secretariat's report on "The Suppression of the Traffic in Persons and of the Exploitation of the Prostitution of Others" (E/CN.5/338). The Association has urged that this report be made available in printed form and has offered to co-operate in plans for wide distribution.

\section{SOME INTERNATIONAL ACHIEVEmEnTS}

As mentioned earlier, the Association's programme is based on an awareness of the importance of international as well as national perspective. International participation ty the A.S.H.A. began with working closely with the League of Nations-later it played a part in the founding of the International Union against the Venereal Diseases. To-day, through its International Division, it takes responsibility for liaison duties for the Union at the United Nations headquarters, and for the servicing of the Union's Regional Office for the Americas. This experience has opened the way to the international co-operation necessary for a real contribution to world health. A similar road of co-operation is available through the Union to all of its member agencies. Citizens of many countries can participate in decisions in this field. Thus through the Union knowledge can be gained, on an informal basis, of the achievements and problems of other countries, a vital force in learning and in working together.

International participation is not necessarily dependent upon a large budget. The A.S.H.A.'s international programme leans heavily on partnerships which have been developed in varied ways, such as by the appointment of an Advisory Committee made up of leading citizens, with experience abroad, both in and out of government; also by a concentrated effort to make new friends at every opportunity and to enlist their interest in and support of programme, as for example, by welcoming visitors from all countries to the Association's office and by attending and participating in meetings, both voluntary and governmental, in this and related fields.

In the United States the rising climate of interest in international health has given the Association, nationally, new opportunities for participation. One example is that information disclosing unmet needs abroad has been sent to the U.S. Senate subcommittee studying American health programmes. Programme suggestions on medical education and research were also forwarded to the World Health Organization to implement a "planning grant in research", which was a contribution to the W.H.O. by the United States. Furthermore, A.S.H.A. has taken an active part in stimulating the co-ordination of the efforts of other non-governmental organizations in the U.S.A. in support of this health movement. By working closely with national committees of such groups as U.N.I.C.E.F., W.H.O., and U.N.E.S.C.O., the American Social Hygiene Association has been able to help interpret their programmes to the public and to enlist public support.

The A.S.H.A.'s International Division has publicized and distributed audio/visual materials wherever possible. Public participation in programmes, both within and outside the U.S.A., has been increased by wide circulation of the Association's educational pamphlets and the development and distribution of similar material in Spanish, written for the general public; by the translation and reprinting of several W.H.O. articles and the circulation of a Spanish newsletter to leaders throughout the Americas.

A separate report on "Activities of the Regional Office of the Americas for the period August, 1957, to September, 1959" is being presented to this Assembly and in it accomplishments of the A.S.H.A.'s international programme (the Union's Regional Office for the Americas) are described more fully.

\section{Summary}

This non-governmental organization has made the following contributions to V.D. control:

(1) Vigilance has been stimulated;

(2) More federal funds have been made available for public health V.D. control;

(3) Social research projects have brought forth important information; 
(4) Educational materials have been widely distributed;

(5) International relationships have been increased and strengthened.

This paper is a description of the efforts of one national member agency of the Union to give assistance to the V.D. control programme in the United States and elsewhere. It is submitted in the knowledge that the U.S.A. provides opportunities for voluntary organization services which differ from those that exist in other countries. However, it is hoped that these remarks may suggest methods of promoting and carrying out services of this and other kinds and may encourage leadership in voluntary effort.

\section{Accomplissements récents d'une organisation non- gouvernementale dans la lutte antivénérienne. \\ Résumé}

Cet article décrit les efforts d'une agence, membre national de l'Union, pour aider dans la lutte antivénérienne aux États Unis et ailleurs. Cette organisation nongouvernementale y a contribué de la manière suivante:

(1) La vigilance fut stimulée;

(2) Plus d'argent fut mis à la disposition de la Santé Publique pour combattre les maladies vénériennes;

(3) Des projets de recherche sociale fournirent des renseignements importants;

(4) Le matériel éducatif fut largement distribué;

(5) Les rélations internationales furent élargies et renforcées.

On présente cet article, sachant que les États Unis offrent à des organisations indépendantes des facilités pour rendre des sevices différents de ceux qui existent dans d'autres pays. On espère, toutefois, que ces observations inspireront la création et la réalisation des services soit semblables soit différents et encourageront l'initiative privée. 